\title{
Rangelia vitalii: changes in the enzymes ALT, CK and AST during the acute phase of experimental infection in dogs
}

Rangelia vitalii: mudanças nas enzimas ALT, CK e AST na fase aguda da infecção experimental em cães

Márcio Machado Costa ${ }^{1 *}$; Raqueli Teresinha França'; Aleksandro Schafer Da Silva²; Carlos Breno Paim¹, Francine Paim ${ }^{1}$; Carlos Henrique do Amaral ${ }^{3}$; Guilherme Lopes Dornelles';

João Paulo Monteiro Carvalho Mori da Cunha ${ }^{1}$; João Fabio Soares ${ }^{4}$; Marcelo Bahia Labruna ${ }^{4}$; Cinthia Melazzo Andrade Mazzanti ${ }^{1}$; Silvia Gonzalez Monteiro ${ }^{2}$; Sonia Terezinha dos Anjos Lopes ${ }^{1}$

${ }^{1}$ Department of Small Animals, Federal University of Santa Maria - UFSM, Santa Maria, RS, Brazil

${ }^{2}$ Department of Microbiology and Parasitology, Federal University of Santa Maria - UFSM, Santa Maria, RS, Brazil

${ }^{3}$ Department of Veterinary Medicine, Federal University of Paraná - UFPR, Curitiba, PR, Brazil

${ }^{4}$ Department of Preventive Veterinary Medicine and Animal Health, University of São Paulo - USP, Brazil

Received October 27, 2011

Accepted June 8, 2012

\begin{abstract}
Rangelia vitalii is a protozoon that causes diseases in dogs, and anemia is the most common laboratory finding. However, few studies on the biochemical changes in dogs infected with this protozoon exist. Thus, this study aimed to investigate the biochemical changes in dogs experimentally infected with $R$. vitalii, during the acute phase of the infection. For this study, 12 female dogs (aged 6-12 months and weighing between 4 and $7 \mathrm{~kg}$ ) were used, divided in two groups. Group A was composed of healthy dogs $(n=5)$; and group B consisted of infected animals $(n=7)$. Blood samples were collected on days $0,10,20$ and 30 after infection, using tubes without anticoagulant to obtain serum and analyze the biochemical parameters. An increase in alanine aminotransferase (ALT) on day $20(\mathrm{P}<0.05)$ was observed. Also, increased creatine kinase (CK) and aspartate aminotransferase (AST) levels were observed throughout the experimental period $(\mathrm{P}<0.05)$. No changes in the serum gamma-glutamyltransferase, urea and creatinine levels were observed. Thus, is possible to conclude that experimental infection with $R$. vitalii in dogs causes changes to the biochemical profile, with increased ALT, AST and CK enzyme levels.
\end{abstract}

Keywords: Rangeliosis, creatine kinase, alanine aminotransferase, aspartate aminotransferase, $R$. vitalii.

\section{Resumo}

Rangelia vitalii é um protozoário que causa doença em cães, sendo a anemia o achado laboratorial mais frequente. No entanto, existem poucos estudos sobre as alteraçôes bioquímicas em cáes infectados com o protozoário. Assim, este estudo tem como objetivo investigar as alteraçôes bioquímicas de cáes experimentalmente infectados com $R$. vitalii na fase aguda da infecção. Para o estudo, foram utilizados 12 cáes fêmeas (com idade entre 6 a 12 meses e peso entre 4 a $7 \mathrm{~kg})$, divididos em dois grupos. O grupo $\mathrm{A}(\mathrm{n}=5)$ foi composto de animais saudáveis e o grupo $\mathrm{B}(\mathrm{n}=7)$ de animais infectados. Amostras de sangue foram coletadas nos dias zero, dez, vinte e trinta PI, utilizando tubos sem anticoagulante para obtenção de soro e análise dos parâmetros bioquímicos. Foi observado um aumento na alanino aminotransferase (ALT) no dia 20 PI $(\mathrm{P}<0,05)$ e aumento na creatinoquinase $(\mathrm{CK})$ e aspartato aminotransferase (AST) em todo o período experimental $(\mathrm{P}<0,05)$. Não foram observadas alteraçôes séricas na gama-glutamiltransferase, uréia e creatinina. Portanto, é possível concluir que a infecção experimental por $R$. vitalii causa alteraçóes no perfil bioquímico, com aumento na ALT, CK e AST.

Palavras-chave: Rangeliose, creatinoquinase, alanino aminotransferase, aspartato aminotransferase, $R$. vitalii.

\footnotetext{
${ }^{*}$ Corresponding author: Márcio Machado Costa Hospital Veterinário, Departamento de Pequenos Animais,

Universidade Federal de Santa Maria - UFSM, Sala 103,

Faixa de Camobi, Km 9, Campus Universitário,

CEP 97105-900, Santa Maria, RS, Brasil

e-mail:marmcvet@yahoo.com.br
} 


\section{Introduction}

Rangelia vitalii is a protozoon of the phylum Apicomplexa, order Piroplasmorida, which is transmitted by the ticks that causes a disease in dogs known as "nambiuvu" or "dog yellow fever". Up until now, the only reports of this disease have come from Brazil (LORETTI; BARROS, 2005; FIGHERA et al., 2010; FRANÇA et al., 2010). Although this parasite was first described in 1908 by Carini, there are only a few studies on this parasite. It is known that ticks of the species Rhipicephalus sanguineus and Amblyomma aureolatum are responsible for transmission, since animals affected by the disease had contact with ticks (LORETTI; BARROS, 2005). This parasite mainly affects young dogs, and usually dogs that are used for hunting, a situation that increases the chance of direct contact with these ticks (FRANÇA et al., 2010).

An association has been established between rangeliosis and a parasite that occurs within endothelial cells, erythrocytes, leukocytes and free-circulation cells (FIGHERA et al., 2010; FRANÇA et al., 2010; DA SILVA et al., 2011). The clinical signs observed in dogs affected by the disease comprise pale mucosa, generalized jaundice, intermittent fever, lethargy, anorexia, weakness, weight loss, splenomegaly, hepatomegaly, generalized lymph node enlargement, dyspnea, petechiae, hematemesis, bloody diarrhea and persistent bleeding from the nostrils, mouth, eyes and ears (KRAUSPENHAR et al., 2003; FRANÇA et al., 2010; DA SILVA et al., 2011). The presence of anemia is one of the most common laboratory findings in cases of rangeliosis, and studies by Fighera et al. (2010) and França et al. (2010) showed that all affected animals developed anemia to different degrees. However, few studies on changes to biochemical parameters in animals infected by $R$. vitalii have been conducted. The disease usually progresses with the presence of intracytoplasmic parasitophorous vacuoles in the endothelial cells of capillaries of various organs and tissues (LORETTI; BARROS, 2004; FIGHERA et al., 2010), and inflammatory infiltrate in organs such as the kidneys, heart and liver (FIGHERA et al., 2010). Thus, the present study aimed to investigate biochemical changes in dogs experimentally infected with $R$. vitalii.

\section{Materials and Methods}

\section{Animals}

Twelve female crossbred dogs aged 6 to 12 months, weighing between 4 and $7 \mathrm{~kg}$, were used. The animals were kept in cages in an experimental room with controlled temperature and humidity ( $25^{\circ} \mathrm{C}$ and $80 \% \mathrm{RH}$, respectively), with free access to water and commercial feed throughout the experiment. All the animals were treated with anthelmintics, vaccinated (Biomax; against distemper, parainfluenza, parvovirus and coronavirus, and against canine leptospirosis) and then underwent a 30-day adaptation period. Complete hemograms and hepatic and renal biochemical panels were performed three times at 15-day intervals. After thirty days (counting from day 0 of the experiment), the patterns evaluated were normal, according to canine reference values (FELDMAN et al., 2000; KANEKO et al., 2008). Before the experiment began, all the animals were free of Babesia spp., R. vitalii, Hepatozoon spp. and Ehrlichia spp. infection, and this was proven through blood tests using a battery of PCR protocols, as described elsewhere (CRIADO-FORNELIO et al., 2006; LABRUNA et al., 2007; SPOLIDORIO et al., 2009; SOARES et al., 2011). The present study was approved by the Animal Welfare Committee of the Federal University of Santa Maria (UFSM), under protocol number $15 / 2010$.

\section{Rangelia vitalii isolates}

The $R$. vitalii strain used in this study was obtained from a naturally infected dog (SOARES et al., 2011). A fresh blood sample from this animal was transferred $(2 \mathrm{~mL}$ through the jugular vein) into a second $\operatorname{dog}$ ( $\operatorname{dog} 13$ : male, five months old) in order to maintain this isolate in the laboratory. This procedure was performed because some information about the biological cycle of this parasite remains unclear, and it remains unknown whether other methods for its maintenance in the laboratory would be successful.

\section{Experimental design}

The animals were divided in two groups: group A consisted of five healthy animals (not infected), which were used as a control group; group B consisted of seven dogs experimentally infected with $R$. vitalii. The infection was transmitted by means of an intravenous injection of $2 \mathrm{~mL}$ of fresh blood collected from dog 13. At the time of inoculation, dog 13 showed the parasite inside erythrocytes and leukocytes in blood smears (procedure described below). Although it was not possible to quantify the number of parasites inoculated, an average of six parasites per slide examined was observed.

\section{Sample collection}

Blood samples for biochemical tests were collected from the jugular vein on days $0,10,20$ and 30 , using $5 \mathrm{~mL}$ disposable syringes and $25 \mathrm{~mm} \times 7 \mathrm{~mm}$ disposable hypodermic needles. Samples were stored in tubes without anticoagulant and centrifuged for 10 minutes, and then the serum was stored at $-20{ }^{\circ} \mathrm{C}$ for subsequent biochemical analysis.

\section{Biochemical parameters}

The serum levels of alanine aminotransferase (ALT), aspartate aminotransferase (AST), creatine kinase (CK), creatinine, gammaglutamyltransferase (GGT) and urea were evaluated in a semiautomatic analyzer (TP Analyzer Plus , Thermoplate, China) using commercial kits (Labtest Diagnóstica S.A., Lagoa Santa, MG, Brazil). All tests were carried out in duplicate.

\section{Pathological findings}

Twenty-one days after infection, one of the dogs from group $\mathrm{B}$ was anesthetized (ketamine at $0.08 \mathrm{~mL} / \mathrm{kg}$ and xylazine at $0.05 \mathrm{~mL} / \mathrm{kg}$ ) and sacrificed using tetracaine chloride (T-6 ${ }^{\circ}$; MSD 
Animal Health). A necropsy was conducted, with collection of fragments of internal organs, such as the liver, kidney, heart and skeletal muscle (gastrocnemius and biceps muscle). The material was stored in $10 \%$ formalin solution. For histopathological evaluation, sagittal sections were obtained with intervals of $3 \mathrm{~mm}$ between regions to mount the slides, and stained with hematoxylin and eosin.

\section{Treatment}

On day 21 after infection, the remaining animals in group $B$ received a single dose of diminazene aceturate $(3.5 \mathrm{mg} / \mathrm{kg})$, intramuscularly as described by Da Silva et al. (2011).

\section{Molecular diagnosis}

On days 10 and 30 after infection, PCR for Rangelia was performed, using a positive control of $R$. vitalii as described by Da Silva et al. (2011).

\section{Statistical analysis}

The results were subjected to analysis of variance and the means were compared using Student's t-test. Values with probability (p) less than 5\% were considered statistically different.

\section{Results}

\section{Infection course and clinical signs}

In all the dogs in group $\mathrm{B}$, forms of $R$. vitalii (probably merozoites) were observed in blood smears five days after infection. The parasitemia increased until days 9 to 11 (peak of parasitemia). Thereafter, the numbers of circulating parasites decreased and many dogs showed negative blood smears as described in detail by Da Silva et al. (2011). The dogs infected with $R$. vitalii (group B) showed increases in their body temperature (control group: $37.8{ }^{\circ} \mathrm{C} \pm 0.31$; infected group: $39.1{ }^{\circ} \mathrm{C} \pm 0.52$ ) five days after infection, compared with the non-infected dogs (group A), and compared with themselves on day zero. Apathy, appetite loss, diarrhea, hyperthermia and increased heart rate were observed in all the animals in group B. Two animals in group B presented mild degrees of jaundice in mucosa and the auricular pinnae on days 20 and 21 after infection.

\section{Biochemical parameters}

Significantly increased levels $(\mathrm{P}<0.05)$ of ALT were observed in the infected dogs only on day 20, in comparison with the noninfected dogs (Figure 1a). The GGT, urea and creatinine levels did not differ between the groups on any of the four evaluation days during the experimental period (Figure 1). The creatine kinase and aspartate aminotransferase concentrations were significantly higher $(\mathrm{P}<0.05)$ on days 10, 20 and 30 after infection, in the dogs infected with $R$. vitalii (Figure 2).

\section{Pathological findings}

The necropsy performed on the $R$. vitalii-infected dog that was sacrificed during the acute phase of the infection (on the $21^{\text {st }}$ day after infection) revealed the following macroscopic alterations: pale mucous membranes, petechiae, hemorrhage (non-coagulated blood), mild jaundice in the costal muscle, thickening of the small intestine, enlarged lymph nodes, splenomegaly and hepatomegaly. Histologically, no changes to the cells of the liver, kidney, heart and skeletal muscles of the dog infected with piroplasm were observed. The parasite was not identified on the slides from these organs.

\section{Treatment}

On day 30 after infection, i.e. nine days after treatment started, all the animals in group B were PCR-negative for the parasite. Therefore, the treatment protocol was 100\% effective, with regard to the blood forms.

\section{Discussion}

Studies on biochemical changes are of significant importance, since they help in making the differential diagnosis of rangeliosis in comparison with other diseases of similar clinical course, such as babesiosis, ehrlichiosis, leishmaniasis and leptospirosis, which are often confused with infection by $R$. vitalii (LORETTI; BARROS, 2004). One of the changes found in the present study was the higher ALT levels on day 20 after infection: even though these levels did not exceed the reference values, they were $41 \%$ greater than on day 0 . Increased ALT levels in dogs are often associated with hepatocellular injury as a result of infectious or toxic inflammatory processes, which promote enzyme release from the cytoplasm of hepatocytes (STOCKHAM; SCOTT, 2011). Higher ALT levels during this period were associated with pathological findings of hepatomegaly and mild jaundice, as reported by Da Silva et al. (2011) in a study that formed part of the same research project as the present study. Hepatomegaly is a common finding in cases of infection by $R$. vitalii, as shown by Fighera et al. (2010), who found it in $88.6 \%$ of their cases in a retrospective study in which 35 dogs with rangeliosis were evaluated. This has also been described by other researchers (LORETTI; BARROS, 2005). However, histologically, no changes that could explain the increased enzyme levels have been seen. The changes found by Fighera et al. (2010) were characterized by mononuclear cell infiltration, which was predominantly plasmacytic. The presence of anemia could also be a cause of increased enzyme levels, since the degree of liver damage caused by hypoxia can vary from moderate to reversible (sublethal cell injury). This sublethal injury may be sufficient for enzymes to cross the cell membrane without loss of functionality. Thus, in cases of severe anemia, the condition of hypoxia promotes passage of ALT through the cell membrane (BUSH, 2004). However, no changes were shown histologically: 

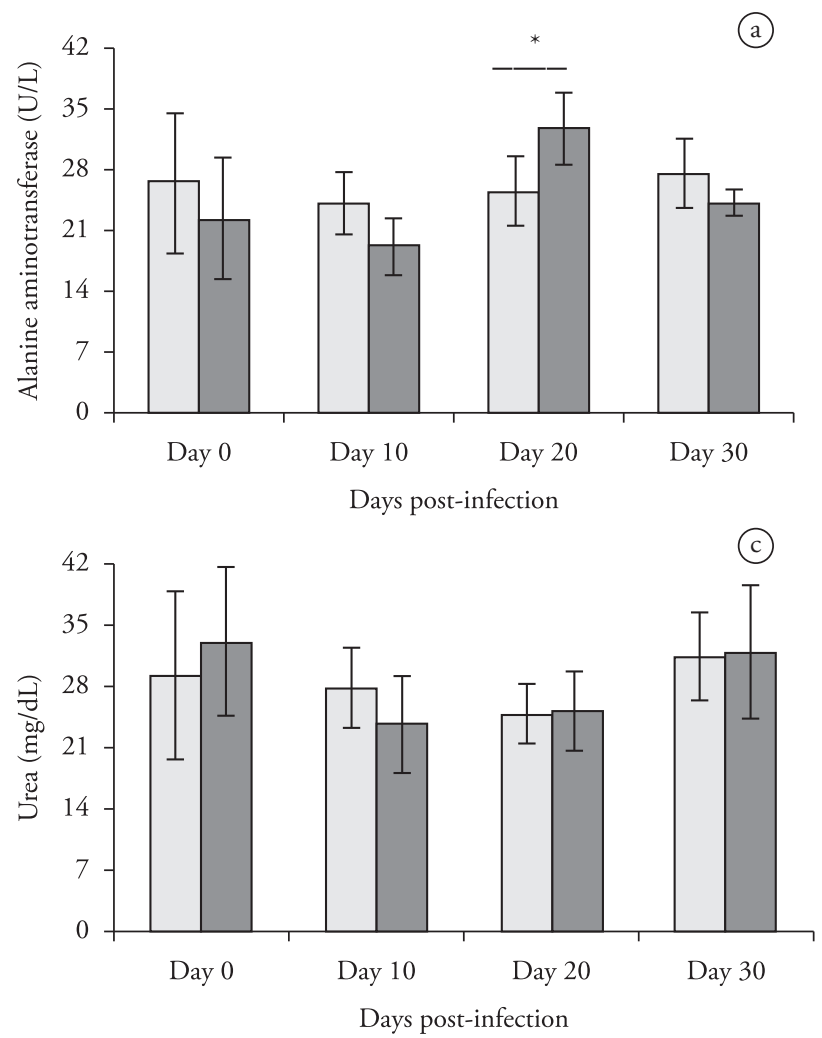

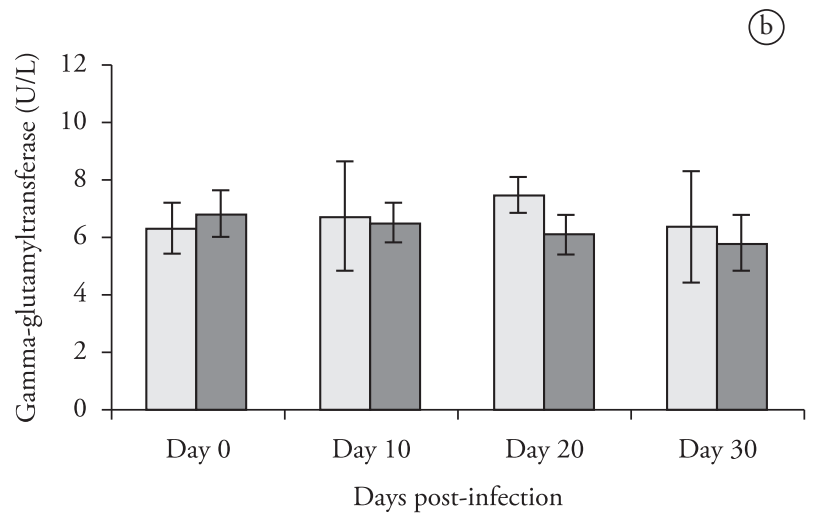

(d)

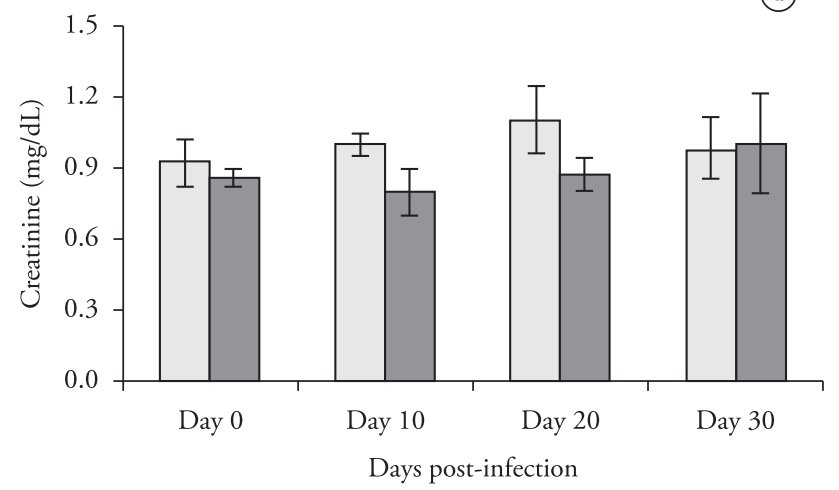

$\square$ Non-infected $\square$ Infected

Figure 1. Levels of alanine aminotransferase (a), gamma-glutamyltransferase (b), urea (c) and creatinine (d) in $R$. vitalii-infected dogs. *Statistical differences were observed between the infected and non-infected groups (Student t test at $P<0.05$ ).
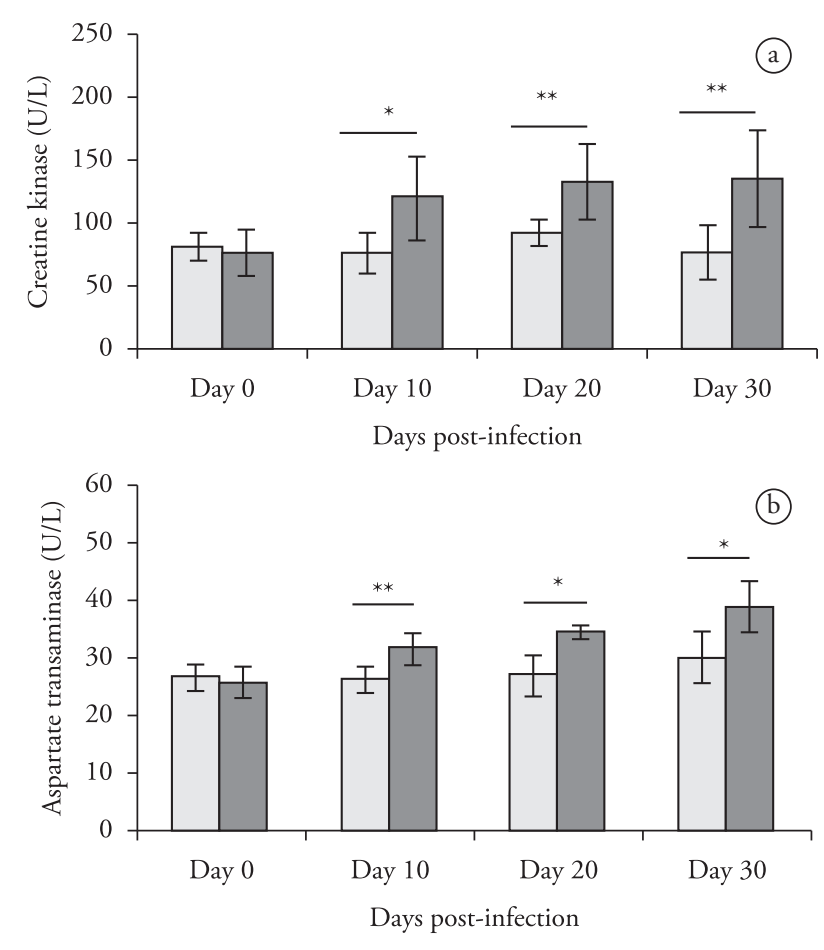

$\square$ Non-infected $\square$ Infected

Figure 2. Muscle enzymatic activity in $R$. vitalii-infected dogs compared with the controls. Levels of creatine kinase (a) and aspartate aminotransferase (b) in infected dogs. ${ }^{*}$ Statistical difference between the infected and non-infected groups (Student t test at $P<0.05$ ). such changes could have included centrilobular degeneration, necrosis or prominent lobular patterns, both on capsular surfaces and on cut surfaces of the organ. These changes are quite frequent in cases of both acute and chronic severe anemia (CULLEN, 2009). Even in the presence of mild jaundice, no increases in GGT levels were observed at any time during the experimental period. GGT is an enzyme found mainly in biliary epithelial cells and increased GGT levels are always related to cholestasis or biliary hyperplasia (STOCKHAM; SCOTT, 2011). When the jaundice is not accompanied by increased enzyme induction, or by alkaline phosphatase or GGT, the causes of jaundice are associated with extravascular hemolysis (THRALL et al., 2007), which promotes prehepatic jaundice. This confirms the findings of anemia seen in this study (DA SILVA et al., 2011).

No changes were found in the kidney, since no increases in either urea or creatinine levels were observed. This absence of changes in renal histopathology, as also discussed in the previous study by Da Silva et al. (2011), strengthens the notion that these metabolites are present at normal levels, thus contrasting with other studies that described inflammatory infiltrates of mononuclear cells in the kidneys (LORETTI; BARROS, 2004; FIGHERA et al., 2010). The findings of the present study help in making differential diagnoses in relation to other diseases caused by piroplasm, such as canine babesiosis, which presents increased levels of urea and creatinine due to nephrotoxicity caused by hemoglobinuria, thereby promoting acute tubular nephrosis and, consequently, acute renal insufficiency (BUSH, 2004). 
Another important finding was the increased CK and AST levels in the infected group from day 10 after infection, which persisted after the treatment with diminazene aceturate. $\mathrm{CK}$ is an enzyme present in skeletal muscle, cardiac muscle, smooth muscle, brain and nerves (THRALL et al., 2007). Increased CK levels in dogs are often related to injury to muscle fibers, thus resulting in release of this enzyme to the bloodstream (STOCKHAM; SCOTT, 2011). It is known that infectious myositis is very rare in dogs, and the most common cause is the infections caused by Leptospira icterohaemorrhagiae (BUSH, 2004). However, muscle damage due to infectious piroplasm such as Babesia sp. has frequently been reported (FURLANELLO et al., 2005; JACOBSON, 2006). One of the complications consists of rhabdomyolysis caused by Babesia rossi infection (JACOBSON; LOBETTI, 1996). Moreover, other researchers have frequently found increased CK levels in cases of severe babesiosis (WELZL et al., 2001). AST is an enzyme present in the cytoplasm and mitochondria of hepatocytes and skeletal and cardiac muscle cells (THRALL et al., 2007). Increased levels of this enzyme were strongly associated with increased CK levels in the present study, since both showed the same profile throughout the experimental period. Even though the reference values were not exceeded, the increase in AST levels in the infected group was more than $50 \%$, compared with day 0 . Thus, the higher serum levels of both enzymes suggests that there was active or recent muscle injury (THRALL et al., 2007). In the present study, there was no histological lesion of muscle tissue that would explain the increased CK and AST levels. However, Fighera et al. (2010) examined muscle tissue from three dogs and detected the presence of round or oval structures compatible with $R$. vitalii, which were present in endothelial cells of capillaries. Another hypothesis for the possible increases in CK and AST levels relates to cardiac lesions, as described by Fighera et al. (2010). These would be characterized by inflammatory infiltration of mononuclear cells and multiple zoites within endothelial cells, which have also been described in babesiosis caused by $B$. canis (LOBETTI et al., 2002). However, no microscopic changes in the heart were observed in one of the dogs in this study, as already discussed by Da Silva et al. (2011).

Based on these results, we can conclude that experimental infection with $R$. vitalii in dogs causes changes to the biochemical profile, as expressed by increased levels of the ALT, CK and AST enzymes, due to possible reversible injuries to the liver and muscles, or changes to the cell membrane permeability of liver and muscle tissues. Even with continuing higher CK and AST levels in the infected group, in comparison with the control, the infected animals were successfully treated with diminazene aceturate, showing clinical signs of improvement with absence of myositis.

\section{References}

Bush BM. Interpretaçâo de Resultados Laboratoriais para Clínicos de Pequenos Animais. São Paulo: Roca; 2004.

Criado-Fornelio A, Ruas JL, Casado N, Farias NA, Soares MP, Müller G, et al. New molecular data on mammalian Hepatozoon species (Apicomplexa: Adeleorina) from Brazil and Spain. $J$ Parasitol 2006; 92(1): 93-99. http://dx.doi.org/10.1645/GE-464R.1
Cullen JM. Fígado, Sistema biliar e pâncreas, In: McGavin MD, Zachary JF. Bases da Patologia em Veterinária. 4th ed. Rio de Janeiro: Elsevier; 2009. p. 393-461.

Da Silva AS, França RT, Costa MM, Paim CB, Paim FC, Dornelles GL, et al. Experimental infection with Rangelia vitalii in dogs: Acute phase, parasitemia, biological cycle, clinical-pathological aspects and treatment. Exp Parasitol 2011; 128(4): 347-352. http://dx.doi. org/10.1016/j.exppara.2011.04.010

Feldman BV, Zinkl JG, Jain NC, Schalm OW. Schalm's Veterinary Hematology. 5th. Philadelphia: Lippincott Williams \& Wilkins; 2000.

Fighera RA, Souza TM, Kommers GG, Irigoyen LF, Barros CSL. Patogênese e achados clínicos, hematológicos e anatomopatológicos da infecção por Rangelia vitalii em 35 cães (1985-2009). Pesq Vet Bras 2010; 30(11): 974-987. http://dx.doi.org/10.1590/S0100736X2010001100012

França RT, Da Silva AS, Paim FC, Costa MM, Soares JF, Mazzanti $\mathrm{CM}$, et al. Rangelia vitalii in dogs in southern Brazil. Comp Clin Path 2010; 19(4): 383-387. http://dx.doi.org/10.1007/s00580-0101041-2

Furlanello T, Fiorio F, Caldin M, Lubas G, Solano-Gallego L. Clinicopathological findings in naturally occurring cases of babesiosis caused by large form Babesia from dogs of northeastern Italy. Vet Parasitol 2005; 134(1-2): 77-85. http://dx.doi.org/10.1016/j. vetpar.2005.07.016

Jacobson LS, Lobetti RG. Rhabdomyolysis as a complication of canine babesiosis. J Small Anim Pract 1996; 37(6): 286-291. http://dx.doi. org/10.1111/j.1748-5827.1996.tb02381.x

Jacobson LS. The South African form of severe and complicated canine babesiosis: clinical advances 1994-2004. Vet Parasitol 2006; 138(1-2): 126-139. http://dx.doi.org/10.1016/j. vetpar.2006.01.047

Kaneko JJ, Harvey JW, Bruss ML. Clinical Biochemistry of Domestic Animals. 6th ed. San Diego: Academic Press; 2008.

Krauspenhar C, Fighera RA, Graça DL. Anemia hemolítica em cães associada a protozoários. Medvep - Rev Cient Med Vet Peq Anim Estim 2003; 1: 273-281.

Labruna MB, Mcbride JW, Camargo LM, Aguiar DM, Yabsley MJ, Davidson WR, et al. A preliminary investigation of Ehrlichia species in ticks, humans, dogs, and capybaras from Brazil. Vet Parasitol 2007; 143(2): 189-195. http://dx.doi.org/10.1016/j. vetpar.2006.08.005

Lobetti R, Dvir E, Pearson J. Cardiac troponins in canine babesiosis. J Vet Intern Med 2002; 16(1): 63-68.

Loretti AP, Barros SS. Parasitismo por Rangelia vitalii em cães ("nambiuvú", "peste de sangue") - uma revisão crítica sobre o assunto. Arq Inst Biol São Paulo 2004; 71(1): 101-131.

Loretti AP, Barros SS. Hemorrhagic disease in dogs infected with an unclassified intraendothelial piroplasm in southern Brazil. Vet Parasitol 2005; 134(3-4): 193-213. http://dx.doi.org/10.1016/j. vetpar.2005.07.011

Soares JF, Girotto A, Brandao PE, Da Silva AS, França RT, Lopes $S T$, et al. Detection and molecular characterization of a canine piroplasm from Brazil. Vet Parasitol 2011; 180(3-4): 203-208. http://dx.doi. org/10.1016/j.vetpar.2011.03.024 
Spolidorio MG, Labruna MB, Zago AM, Donatele DM, Caliari KM, Yoshinari NH. Hepatozoon canis infecting dogs in the State of Espírito Santo, southeastern Brazil. Vet Parasitol 2009; 163(4): 357-361. http:// dx.doi.org/10.1016/j.vetpar.2009.05.002

Stockham SL, Scott MA. Fundamentos de patologia clínica veterinária. 2nd ed. Rio de Janeiro: Guanabara Koogan; 2011.
Thrall MA, Baker DC, Campbell TW, Denicola D, Fettman MJ, Lassen $\mathrm{ED}$, et al. Hematologia e bioquímica clínica veterinária. São Paulo: Roca; 2007.

Welzl C, Leisewitz AL, Jacobson LS, Vaughan-Scott T, Myburgh E. Systemic inflammatory response syndrome and multiple-organ damage/dysfunction in complicated canine babesiosis. J $S$ Afr Vet Assoc 2001; 72(3): 158-162. 